\title{
FORMATION OF READING LITERACY OF PUPILS BY MEANS OF PHYSICS
}

\author{
Halyna Voitkiv \\ $\mathrm{PhD}$, Associate Professor at the Department of Physics and Methods of Teaching, \\ Vasyl Stefanyk Precarpathian National University, Ukraine \\ e-mail: h.voitkiv@gmail.com,orcid.org/0000-0002-2158-9577
}

\section{Summary}

Based on the theoretical analysis, the concepts of reader literacy and reading competence are researched and formulated, and the structure of reader literacy is determined. The author considers the components of reading literacy, which are formed in the process of studying physics through the components of key competencies identified by the program. The most characteristic types of visual presentation of information in physics textbooks are also identified and its significance for the formation of both subject competence in physics and the experience of reading such information. The contribution of physics to the formation of developmental and activity components of reading competence is determined and certain generalizations and recommendations for enriching the experience of reading activities of various texts especially those containing graphs and tables are formulated. The author substantiates the hypothesis of increasing the level of reading literacy of main school students by formulating certain metacognitive reading strategies and generalized conclusions and recommendations when working with subject graphics.

Keywords: reading competence, reading experience, various texts, types of visual information, reading graphs, charts, tables.

\section{DOI: https://doi.org/10.23856/3831}

\section{Introduction}

We live in a world where the amount of information is growing at an unstoppable pace. The development of information and communication technologies has also led to the emergence of a large amount of electronic information that penetrates into all spheres of life. Changing the nature of information, increasing the amount of information we process daily from various sources, increasing the formats of its presentation, the educational community faces the task of finding quality methods to develop the school pupils skills to work with such information and learning the knowledge needed in today's world.

In the process of learning activities, pupils will receive new information to a greater extent through reading activities. Reading skills, which were considered necessary for success in learning and in life a few decades ago, are different from those needed today. Today it is important to understand the context of the material read, the ability to quickly get acquainted with a large number of different information and highlight its main aspects, analyze for further conclusions and use. The very interpretation of the text has also changed. Therefore, the issue of forming reading skills in the pupils of main school for successful further self-realization and lifelong learning is relevant today. The purpose of the work is finding out the essence of the concept of "reading literacy" and the possibility of the subject of physics for the formation of reading literacy in pupils. 


\section{The concept of reading literacy and reading competence in the research of scientists}

The development of technology is constantly changing the nature of receiving, reading and exchanging information. Today, life forces us to use not only printed information, but also electronic. More and more information is presented in a compact form using various forms of visual representation of a material, which in turn requires special reading skills (Waters, Schneider, 2010). In the scientific, psychological and pedagogical literature there are the concepts of "reading literacy", "reading competence", "reading skills" (Smetannikova, 2009; Westhoff, 1997; Savchenko, 2011 etc). The concept of reading competence is associated with the ability of an individual to read in order to acquire new knowledge that helps in practical life and further learning (Orlova, 2008). A number of researchers consider reading competence "as a collective integrative personal quality that contains both developmental (development of thinking, reading mechanisms, formation of emotional and volitional sphere) and activity components (formation of reading skills and strategies - goal setting, search and analysis of information, understanding and text interpretation, evaluation and formation of judgments about the text), which correspond to the tasks of each level of education" (Smetannikova, 2009; Savchenko, 2011).

The formation of reader literacy is possible only in the process of reading, which is an active, purposeful process of perception, comprehension, interpretation and evaluation of the read textual information. Reading activities are different at each level of education.

\section{Reading literacy of main school pupils}

It should be noted that in most methodological studies of domestic scholars the content and structure of reading competence was considered on the basis of studying the subjects of language and literature in primary school and Ukrainian and foreign fiction in high school (Chepelieva, 2004).

Foreign researchers began to study the issues of reading literacy of main school pupils in the framework of the international monitoring study PISA (The Organisation for Economic Co-operation and Development, 2018). In this investigations we read :- the ability to read visual texts, written by hand or printed on the screen, which can exist both independently and be part of larger texts, is defined as reading ability; - reading skills are the basis for full participation in the economic, political, social and cultural life of modern society; the term "text" refers to all language that is represented in graphic form: handwritten, printed or on the screen, visual images such as diagrams, illustrations, maps, tables, graphs and comics that contain elements of written speech (eg captions) (OECD, 2018: 13).

Reading in the form in which it occurs in everyday life (reading newspapers, posters, ads, social networks, educational sites, formulas, etc.) is a reading activity. The expansion of the field of reading (the emergence of electronic texts, different types of visualization) necessitates a broader definition of "reading skills", which includes both basic reading processes (learned in primary school) and higher level skills - reading different types of visualization and digital reading (Leu et al., 2013; Taboada, Tonks, Wigfield, Guthrie, 2013).

Based on the research, we can say that the formation of reading literacy and reading skills does not end in primary school, but continues throughout school, and has different tasks in accordance with the objectives of education at each level of education. According to the results of the monitoring study (2018), conducted for 4-th grade pupils (Ukrainskyi tsentr otsiniuvannia yakosti osvity, 2019) and 15-year-olds to determine the level of their literacy (OECD, 2018), 
it is clear that there is a gap of $12,1 \%$ between the number of primary school children, who have reached the basic level of reading literacy and the number of main school children. The basic level of reading literacy was set for each age period.

For 15-year-old pupils, "basic reading literacy is defined as the level at which pupils can not only read simple and familiar texts and understand them in a straightforward manner, but also demonstrate, even in the absence of clear instructions, a certain ability to connect several pieces of information to draw conclusions that go beyond the information explicitly stated in the text, and to link information from the text with their own experience and knowledge" (Mazorchuk, Vakulenko, Tereshchenko, Bychko, Shumova, Rakov, Horokh, 2018). The analysis of the questionnaires showed that the main reasons for the presence of a large number of main school pupils $(25,9 \%)$ who did not reach the basic level of reading literacy are low motivation to read in general and lack of experience in reading texts containing tables, charts and graphs, hyperlinks (Mazorchuk and other, 2018).

\section{The contribution of physics to the formation of reader literacy}

Physics as a subject also contributes to the formation of reading literacy, it is physics that has the opportunity to form the experience of reading graphs, charts, tables and more (Kovalenko, 2016). Analysis of normative documents and programs in physics has shown that the separate concept of "reading skills" or "reading literacy" does not occur, but we can identify some of their components through which they are expressed. These components are components of key competencies (Table 1) (Liashenko and other, 2017).

Table 1

\section{Components of reading skills in key competencies}

\begin{tabular}{|l|l|}
\hline \multicolumn{1}{|c|}{ Key competencies } & \multicolumn{1}{|c|}{ Components } \\
\hline $\begin{array}{l}\text { Communication in } \\
\text { the state (and native }- \\
\text { in case of difference) } \\
\text { languages }\end{array}$ & $\begin{array}{l}\text { Skills: } \\
- \text { understand information from textbooks, manuals and other textual and } \\
\text { media sources in the state / native language; } \\
\text { - present textual information in another form. }\end{array}$ \\
\hline $\begin{array}{l}\text { Communication in } \\
\text { foreign languages }\end{array}$ & $\begin{array}{l}\text { Skills: } \\
\text { - use foreign language educational and popular science sources to obtain } \\
\text { information of physical and technical content, self-education and self-devel- } \\
\text { opment. }\end{array}$ \\
\hline $\begin{array}{l}\text { Mathematical } \\
\text { competence }\end{array}$ & $\begin{array}{l}\text { Skills: } \\
\text { - apply mathematical methods to describe, process and evaluate the results } \\
\text { of the experiment. }\end{array}$ \\
\hline $\begin{array}{l}\text { Information and } \\
\text { digital competence }\end{array}$ & $\begin{array}{l}\text { Skills: } \\
- \text { identify possible sources of information, select the necessary information, } \\
\text { evaluate, analyze, recode information; } \\
\text { - use modern devices to receive, process, store, transmit and present infor- } \\
\text { mation }\end{array}$ \\
\hline $\begin{array}{l}\text { Ability to learn } \\
\text { throughout life }\end{array}$ & $\begin{array}{l}\text { Skills: } \\
- \text { to apply the acquired knowledge for mastering new ones, for their system- } \\
\text { atization and generalization. }\end{array}$ \\
\hline $\begin{array}{l}\text { Initiative and } \\
\text { entrepreneurship }\end{array}$ & $\begin{array}{l}\text { Skills: } \\
- \text { to evaluate the possibility of applying the acquired knowledge of physics } \\
\text { in future professional activities, to effectively solve everyday problems. }\end{array}$ \\
\hline
\end{tabular}


From the table we see that the skills to be formed in pupils in the study of physics correlate with the components of key competencies. Therefore, selecting the means and methods for the formation of subject and key competencies, the teacher will form both the developmental and activity components of reading literacy. We will pay special attention to the possibilities of physical material for the formation of metacognitive strategies and to enrich the experience of reading. Correct reading experience and elements of reading strategies are formed in physics lessons when working with textbook texts, workbooks, instrument manuals, device passports, online sources and sites for studying physics, when performing laboratory work necessarily under the guidance and assistance of a teacher. Such metacognitive strategies of reading should include: setting goals for reading (understand the instructions, memorize the rule, highlight the main idea, find commonalities or differences, etc.); adaptation of reading depending on the set goals (this includes tips or recommendations of the teacher on how best to achieve the set goals); knowledge of how to summarize what is read or memorize important information (for example, the use of memo descriptions of the device, the phenomenon, the algorithm for processing graphs of certain types); knowledge of how to solve problems with understanding (solve a problem, take a test, answer questions on a topic, etc.) (Waters, 2010).

Due to the use of computer technologies in the educational process and life, we often deal with mixed text formats, which contain both fixed texts and dynamic (Waters, Schneider, 2010). Fixed texts are texts with a given linear structure, instructions, almost no navigation elements. They can be presented both in printed format and in electronic form. Dynamic texts have a more complex, non-linear organization and many navigation elements. To build their own text, the reader should have self-regulated reading, which means: the integration of physical actions such as clicking, scrolling down with cognitive processes, such as forecasting, evaluating and analyzing the quality of information. Pupils gain experience reading fixed texts by working with textbooks and clearly defined linear texts on the Internet. It is more difficult for a teacher to organize activities to gain experience working with dynamic texts. Within the curriculum, this can be organized in the project activities of pupils. Both fixed and dynamic physics texts have a lot of visual information. Visualization is the presentation of information, data, facts in a visual form (Ukrainskyi tsentr vidkrytykh danykh, 2015). The main tasks of visualization are to interest, motivate and make more compact large amounts of information more accessible to perception. According to statistics, among the most used types of visualization in texts are histograms; bar charts; line diagrams (graphs), scattering diagrams and bubble diagrams; pie charts; table as a visualization technique (Ukrainskyi tsentr vidkrytykh danykh, 2015-2020). School physics, due to its specificity, makes a significant contribution to the formation of the experience of "reading" tables, graphs, as well as formulas, models, diagrams, reading data from the dials of ana$\log$ and electronic devices.Graphs, as a type of visual information, allow you to effectively show a variety of relationships, relationships between different variables. It is worth noting that graphical dependencies are studied in the course of mathematics, but the use of these graphical dependencies on real-life examples is inherent physics course. The contribution of physics to the experience of reading is given in the tables 2-3.

The table provides information on the use of graphical visualization, such as graphs, charts, nomograms, geometric constructions in physics to explain and better understand the subject (Kovalenko, 2016; Liashenko an oth., 2017) provided by the requirements of physics programs, and formulates some generalizations, recommendations, conclusions for visual information reading that can be used in the future for conscious reading of various texts. 
The contribution of physics to the experience of reading (Mechanics)

\begin{tabular}{|c|c|c|}
\hline $\begin{array}{l}\text { Physics } \\
\text { section }\end{array}$ & $\begin{array}{c}\text { Use of graphical visualization } \\
\text { in physics }\end{array}$ & Gained experience for reading activities \\
\hline Mechanics & $\begin{array}{l}\text { Body movement graphs; graphs of } \\
\text { body speed; the method of graph- } \\
\text { ical integration to determine the } \\
\text { path traveled by the body; using } \\
\text { the graphical method to formu- } \\
\text { late the concept of the average } \\
\text { speed of non-uniform rectilinear } \\
\text { motion; consideration of oscillatory } \\
\text { motions; consideration of concepts: } \\
\text { momentum, work, power; demon- } \\
\text { stration of the dependence of the } \\
\text { force of elasticity on deformation; } \\
\text { demonstration of the dependence of } \\
\text { the acceleration of free fall on the } \\
\text { distance of the body to the Earth's } \\
\text { surface; description of the features } \\
\text { of the force of friction at rest; depen- } \\
\text { dence of work on time; changes in } \\
\text { kinetic energy, potential energy of a } \\
\text { deformed body and potential energy } \\
\text { of a body raised above the Earth in } \\
\text { closed systems }\end{array}$ & $\begin{array}{l}\text { Graphs - a way to set the functional dependence; graphic } \\
\text { method - a method of scientific research; graphical and } \\
\text { tabular presentation of measurement results; skills of anal- } \\
\text { ysis of graphs and determination of additional parameters } \\
\text { according to graphs, implementation of additional cal- } \\
\text { culations or indirect measurements; extrapolation of the } \\
\text { obtained results to simplify individual calculations and } \\
\text { calculations; understanding the hypothesis of "direction" } \\
\text { of the graph; understanding that data points in the coor- } \\
\text { dinate plane can show both a trend and typical deviations } \\
\text { from it; "whiskers" added to the points on the graph show } \\
\text { the limits of probable error; the experimental curve as a } \\
\text { band of a certain thickness can show the limits of prob- } \\
\text { able error (ie deviation of theoretical calculations from } \\
\text { experimental measurements); in line diagrams there can be } \\
\text { a combination of several lines, which is very convenient } \\
\text { for comparing the parameters of several similar objects; } \\
\text { the color or type of reference lines on one coordinate plane } \\
\text { is used to encode different dependencies; understanding of } \\
\text { scaling on axes and when denoting three or more variables; } \\
\text { reading graphic images of functional dependencies that } \\
\text { underlie various technological installations, structures and } \\
\text { machines; understanding a bar chart in which each column } \\
\text { consists of layers, the thickness of each of which encodes } \\
\text { a variable, the sum of which is a significant whole (read- } \\
\text { ing energy charts in which each type of energy for a given } \\
\text { stage is presented as a rectangle with height or width corre- } \\
\text { sponding to the energy value). }\end{array}$ \\
\hline
\end{tabular}

Table 3

The contribution of physics to the experience of reading (Molecular physics and thermodynamics, Electricity, Optics, Atomic and nuclear physics)

\begin{tabular}{|c|c|c|}
\hline Physics section & Use of graphical visualization in physics & $\begin{array}{c}\text { Gained experience } \\
\text { for reading activities }\end{array}$ \\
\hline 1 & 2 & 3 \\
\hline $\begin{array}{l}\text { Molecular physics } \\
\text { and thermodynam- } \\
\text { ics }\end{array}$ & $\begin{array}{l}\text { Use of graphs to describe thermal processes, } \\
\text { in particular melting and crystallization of sol- } \\
\text { ids, evaporation and condensation of liquids, } \\
\text { boiling; the use of diagrams for the analysis of } \\
\text { energy conversion in thermal processes, ther- } \\
\text { mal balance as a consequence of the law of con- } \\
\text { servation of energy in thermal processes; use of } \\
\text { models to demonstrate the principle of opera- } \\
\text { tion of heat engines; graphic representation of } \\
\text { isoprocesses in gases; phase transitions in ther- } \\
\text { modynamics; use of models to depict types of } \\
\text { crystal lattices. }\end{array}$ & $\begin{array}{l}\text { Graphic method - a way to set the } \\
\text { functional dependence; understand- } \\
\text { ing and reading diagrams; work with } \\
\text { models; understanding and reading } \\
\text { on graphs the dynamics of phenom- } \\
\text { ena and processes; use of prognostic } \\
\text { function at the analysis of the sched- } \\
\text { ule for clarification of "behavior" } \\
\text { of the investigated variable; reading } \\
\text { instructions in the workplace, the } \\
\text { ability to interpret the results of the } \\
\text { experiment on schedule. }\end{array}$ \\
\hline
\end{tabular}


Table 3 (Continued)

\begin{tabular}{|c|c|c|}
\hline 1 & 2 & 3 \\
\hline Electricity & $\begin{array}{l}\text { Explanation of concepts: wavelength, ampli- } \\
\text { tude of oscillation, period, resonance, phase, } \\
\text { phase shift in electromagnetic oscillations with } \\
\text { the help of graphic images; using graphs show } \\
\text { the dependence of the resistance of the conduc- } \\
\text { tor on the length at a constant cross-sectional } \\
\text { area, the dependence of the resistance of the } \\
\text { conductor on its cross-sectional area at a con- } \\
\text { stant length, illustration of the dependence of } \\
\text { current on voltage and electrical resistance; } \\
\text { electrical resistance to temperature for metals } \\
\text { and semiconductors, the use of nomograms to } \\
\text { determine the resistance of any number of con- } \\
\text { ductors connected in parallel. }\end{array}$ & $\begin{array}{l}\text { Visual representation of the relation- } \\
\text { ship between quantities; combination } \\
\text { of formula and graph for the forma- } \\
\text { tion of concepts; reading and calcu- } \\
\text { lations of electrical circuits both ana- } \\
\text { lytically and using nomograms. }\end{array}$ \\
\hline Optics & $\begin{array}{l}\text { Use of constructions for understanding and } \\
\text { analysis of the course of rays in lenses; solv- } \\
\text { ing problems on the application of the laws of } \\
\text { geometric optics, on the calculations of optical } \\
\text { systems. }\end{array}$ & $\begin{array}{l}\text { Recognition, understanding and } \\
\text { analysis of geometric optics con- } \\
\text { structions; nomogram analysis skills. }\end{array}$ \\
\hline \multirow[t]{2}{*}{$\begin{array}{l}\text { Atomic and nuclear } \\
\text { physics }\end{array}$} & $\begin{array}{l}\text { Using a graph of the dependence of radionu- } \\
\text { clide activity on time. }\end{array}$ & \\
\hline & $\begin{array}{l}\text { Use of nomograms; reading of semi-quantita- } \\
\text { tive graphs (in which not only numerical values } \\
\text { are plotted on the axes, but the ratio of quan- } \\
\text { tities, conditional values of quantities or the } \\
\text { value of a quantity is set through the number of } \\
\text { conditionally accepted values); ability to read or } \\
\text { submit the dependence on the third value in the } \\
\text { quantitative graph. }\end{array}$ & \\
\hline
\end{tabular}

\section{Conclusions and suggestions}

Thus, reading literacy is an integrative quality of personality that includes both components of development and activity, elements that correlate with the components of key competencies. Reading literacy is improved and developed through the experience of conscious reading in the learning process. The components of students' reading literacy in physics lessons are formed by the teacher, forming the key competencies defined by the program. Physics texts also make a special contribution to the formation of reading literacy of technical texts or texts with visualization. Enrichment of experience and formation of strategies for reading technical texts or texts with many types of visualization, such as graphs, charts, diagrams, tables, occurs in the formation of subject physical competence, by formulating certain conclusions, general recommendations, algorithms for reading graphs that can be used in such cases or texts. Prospects for further research are the development of generalized recommendations for each topic in physics, which contains elements of the considered types of visual representation of information, which would be used as a guide for reading various texts. 


\section{References}

Chepelieva, N.V. (2004) Tekhnolohii chytannia [Reading technology]. Kyiv: Hlavnyk. [in Ukrainian]

Kovalenko, K.V. (2016) Formuvannia predmetnoi kompetentnosti uchniv osnovnoi shkoly u protsesi rozviazuvannia fizychnykh zadach hrafichnym metodom [Formation of subject competence main school pupils in the process of solving physical problems graphically]. Kyiv. [in Ukrainian]

Liashenko, O. I., Bariakhtar, V. H., Blahodarenko, L. Yu. Holovko, M. V., Horobets, Yu. I., Zasiekina, T. M., Liskovych, O. V., Martyniuk, M. T., Nenashev, I. Yu, Okhrymenko, N. A., Syrotiuk,V. D., Shut, M. I. (2017). Fizika. Navchalna programa dlya 7-9 klasiv ZNZ [Physics curriculum for grades 7-9 of secondary schools]. Kyiv. [in Ukrainian]

Leu, D. J., Kinzer, C. K., Coiro, J., Castek, J., \& Henry, L. A. (2013). New literacies: A duallevel theory of the changing nature of literacy instruction and assessment. In D. E. Alvermann, N. J. Unrau, \& R. B. Rudell (Eds.), Theoretical models and processes of reading (6th edition, pp. 1150-1181). Newark: International Reading Association.

Mazorchuk, M., Vakulenko, T., Tereshchenko, V., Bychko, H., Shumova, K., Rakov, S., Horokh, V. (2018). Natsionalnyi zvit za rezultatamy mizhnarodnoho doslidzhennia yakosti osvity PISA2018 [National report on the results of the international survey on the quality of education PISA-2018].Kyiv: UTSOIaO. [in Ukrainian]

OECD. (2018). PISA 2018. Ramkovij dokument z gramotnosti chitannya [PISA 2018 Framework Document on reading literacy]. Pirson: mizhnarodnyj partner (Core B).[in Ukrainian] OECD. (2018). PISA 2018 Ramkovyi dokument do opytuvalnyka [PISA 2018 framework document to the questionnaire]. Pirson: mizhnarodnyj partner (Core B). [in Ukrainian]

Orlova, E. A. (2008). Rekomendacii po povysheniyu urovnya razvitiya chitatelskoj kompetentnosti $v$ ramkah Nacionalnoj programmy podderzhki i razvitiya chteniya: posobie dlya rabotnikov obrazovatelnyh uchrezhdenij [Recommendations for raising the level of development of reading competence in the framework of the National program of support and development of reading: a guide for employees of educational institutions]. Moskva. [in Russian]

Smetannikova, N. N. (2009). Kompetencii chteniya i kompetentnyj chitatel [Reading competencies and a competent reader]. Moskva:Nauka. [in Russian]

Savchenko, O. Ia. (2011). Kliuchovi kompetentnosti - innovatsiinyi rezultat shkilnoi osvity [Key competencies - an innovative result of school education]. Ridna shkola, № 8-9, 4-8. [in Ukrainian]

Taboada, A., Tonks, S. M., Wigfield, A., \& Guthrie, J. T. (2013). Effects of motivational and cognitive variables on reading comprehension. Newark: [International Reading Association]. Ukrainskyi tsentr otsiniuvannia yakosti osvity (2019). Zvit pro rezultaty pershoho tsyklu zahalnoderzhavnoho monitorynhovoho doslidzhennia yakosti pochatkovoi osvity "Stan sformovanosti chytatskoi ta matematychnoi kompetentnostei vypusknykiv pochatkovoi shkoly zakladiv zahalnoi serednoi osvity" $2018 \mathrm{r}$. Chastyna III. Chytannia [Report on the results of the first cycle of the national monitoring study of the quality of primary education "The state of formation of reading and mathematical competencies of primary school graduates of general secondary education" in 2018, Part III. Reading]. Kyiv. [in Ukrainian]

Ukrainskyi tsentr vidkrytykh danykh (2015). Vidkrytyi posibnyk z vidkrytykh danykh [An open guide to open data]. Retrieved from https://socialdata.org.ua/manual0/

Waters, H. S., \& Schneider, W. (2010). Metacognition, strategy use, and instruction. New York: Guilford Press.

Westhoff, G. (1997). Reading skills. Muenchen: Goelthe-Institut. [in Deutch]. 